sing community and, although not quite so pressing with the advent of parallel and special-purpose computers, it will surely always be important for archival purposes. Various ways of coding images that occupy less memory space have been explored, and Roger Clarke's book is a detailed introductory account of one of these ways, notably the use of transforms, of which the Fourier is the best known.

The underlying idea is simple. Fourier transforms tell us what weight is associated in some signal with the corresponding frequency. We can therefore expect that if we suppress frequencies with very low weights, and reconstruct the signal from the remainder, the result will differ only slightly from the original. Converting this qualitative notion into quantitative terms is not so simple: how low must a weight be to be regarded as very low and hence negligible? How slight must the difference between original and reconstruction be to be acceptable? Is the Fourier transform a good choice and if not, which is the best transform to use? It is these and related questions that Clarke sets out to answer. He does so in eight chapters, plus an introduction, in which he examines image statistics, suitable orthogonal transforms, quantization, practical coding, the human visual response, fast transforms, errors and noise and, finally, rate distortion theory and coding. Seven appendices are concerned with specific mathematical points.

How successful he is depends on the sophistication of the reader. Everything is spelt out in detail: the laboriously gentle introduction of a matrix product at the beginning of the chapter on orthogonal transforms is a glaring example. Any physicist who has followed a course on quantum mechanics, not to say applied mathematics, will be exasperated by this, as will many electrical engineers, especially those with any familiarity with coding. Conversely, many readers will appreciate the detailed and careful definition of the many matrices that arise in image coding, and will be grateful for the frequent numerical examples that add flesh to the bare mathematical bones.

It must be said too that Clarke's is a leisurely style: "At the outset, it is worth clarifying one matter concerning the application of the theory . . .", he observes; and he likes telling us that "it is a truism nowadays to say" and that "it is no exaggeration to say that . ..". His discursiveness seems at odds with the aim of transform coding! Nevertheless, he has written a clear, readable and easy introduction to his subject, and those of us with images to code will often turn to his book to see what he has to say about some specific problem.

Peter Hawkes is Directeur de Recherche at the Laboratoire d'Optique Electronique du CNRS, BP 4347, F-31055, Toulouse Cedex, France.

\section{Catalogue of inequities}

\section{John Maddox}

The World of Science and the Rule of Law. By John Ziman. Paul Sieghart and John Humphrey. Oxford University Press: 1986. Pp. 343.£19.50, \$37.

Tuis is not so much a book about the world of science and the rule of law as about what are called, in the United States, human rights - conflicts between personal liberty and the interests of the state. John Ziman. Paul Sieghart and J. H. Humphrey are, respectively. distinguished physicists. lawyers and biologists whose interests have repeatedly strayed beyond the narrow boundaries of their professions. Their failure, in this book, to do much more to describe a haunting problem is not their fault, but a measure of its difficulty.

The book has its origins in a pamphlet published more than ten years ago by the British organization called the Council for Science and Society, an unpaid and sometimes unprofessional Office of Technology Assessment. The starting point is the observation that the complaints of scientists that their professional freedom is too often administratively constrained is often at odds with the way in which most formal constitutions formally guarantee the freedom of the individual to do what he pleases.

Given the signature of the agreements on European security at Helsinki in 1979. the book cannot but in part be an account of the lamentable record of what has happened since. But little has changed. People who work in states where freedom of communication is guaranteed by the laws still discover that their letters are opened, sometimes to be confiscated, and their telephones disconnected. People whose governments are supposedly bound by the rule that employment should be open to all still find themselves denied the chance to work at what they do best when they give offence; the case of the Jewish refusniks in the Soviet Union is familiar. and necessarily a large part of the litany of oppression making up this book. Indeed, the Eastern bloc gets a real drubbing.

The authors might have made more of the way in which many western European States have been compelled by the European Convention on Human Rights to do the decent thing, against their first inclinations. Maybe there is more freedom now than, say. in the eighteenth century. even though the continuing deficiency of what is on offer remains just as offensive now as then. So the authors are right to ask why performance should so often fall short of promise. Why? A discussion of this point would have been rewarding

The truth is that the human failing of believing well and hehaving badly applies to governments as well. Let us hope they may improve. How might the professional community urge them on! After what is a moving catalogue of unjustice. the authors have next to nothing to offer by way of remedy. They approve of the way that two successive presidents of the Royal Society have "spoken out". but have surprisingly little to say about the need for the outspoken to contain their protests within the other fellow's law. UNESCO's statements on the status of scientific workers are approvingly reprinted as an appendix, but the authors seem to share the general conviction that the souree of all the words has no act to perform: ICSU is a better bet. Weisskopf 's dilemma. that an illiberal society ostracized into exclusion can only become even more illiheral. is described but not resolved. And nowhere in this flat peroration is there a clear explanation. for the benefit perhaps of the young and cynical. of why it is that if the law has a built-in momentum sweeping illiberality out of the way, then surely science must work the same magic but more powerfully. But is that not the only way in which it will come out?

Johm Maddox is editor of Nature

\begin{tabular}{|c|}
\hline $\begin{array}{l}\text { NEW TITLES } \\
\text { BY ANS }\end{array}$ \\
\hline $\begin{array}{c}\text { IMAGE } \\
\text { UNAVAILABLE } \\
\text { FOR } \\
\text { COPYRIGHT } \\
\text { REASONS }\end{array}$ \\
\hline $\begin{array}{l}\text { "Introductory Nuclear } \\
\text { Reactor Statics"' } \\
\text { by Karl } 0 \text {. Ott } \\
\text { Winfred A. Bezella }\end{array}$ \\
\hline $\begin{array}{l}\text { Recommended as an undergraduate or } \\
\text { graduate textbook. Valuable source } \\
\text { book for reactor analysis and design. }\end{array}$ \\
\hline $\begin{array}{c}\text { "Introductory Nuclear } \\
\text { Reactor Dynamics" } \\
\text { by Karl } 0 . \text { Ott } \\
\text { Robert J. Neuhold }\end{array}$ \\
\hline $\begin{array}{c}\text { Examines fundamental principles of } \\
\text { Nuclear Dynamics. Companion volume } \\
\text { to Nuclear Reactor Statics, published } \\
\text { in } 1983 .\end{array}$ \\
\hline $\begin{array}{c}\text { For additional intormation write. } \\
\text { American Nuclear Society } \\
555 \text { North Kensington Avenue } \\
\text { La Grange Park, IL } 60525 \text { USA }\end{array}$ \\
\hline
\end{tabular}

Reader Service No.7 